\title{
The Cumulative Effect of Manure on a Festuca Rubra Grasslands for 15 Years
}

\author{
Ioana VAIDA, Ioan ROTAR*, Florin PACURAR \\ Faculty of Agriculture, University of Agricultural Sciences and Veterinary Medicine, Cluj-Napoca \\ Calea Mănăștur 3-5, 400372 Cluj-Napoca, Romania \\ * corresponding author: rotarioan52@yahoo.fr
}

Bulletin USAMV series Agriculture 74(2)/2017

Print ISSN 1843-5246; Electronic ISSN 1843-5386

DOI 10.15835/buasvmcn-agr: 0015

\begin{abstract}
Over time, studies of the vegetation of natural grasslands have evolved from simple observations to rigorous research. Feed obtained from natural meadows without major technological imputations is mediocre in quality, and pastures in a rather advanced state of degradation.

The main purpose of this paper is the ecological and fodder evaluation of the Festuca rubra type of grasslands in the Apuseni Mountains based on the floristic composition and the productivity of these grasslands.

The experience was carried out in Ghetari village, Apuseni Mountains, which was located in 2001, following the method of randomized blocks with 4 experimental variants in 4 rehearsals. Each variant were fertilized with organic inputs using the same quantities each year. In the paper we use the results obtained after 15 years of experience.

The application of organic fertilizers caused significant changes in the canopy causing changes in the dominance of the type of grassland. The livestock manure applied on the studied grassland has increases significant yield production at all variants of fertilization.

In this paper it was shown on which species the productivity of the grassland increased from the control variant to the fertilized variant with the maximum dose. Regarding the analysis of the phytodiversity, this tells us if the number of species is reduced in all the treatments, $10 \mathrm{t} / \mathrm{ha}$ of manure leads to an increase in phytocoenosis equivalence and implicitly to the Shannon index.
\end{abstract}

Keywords: organic fertilization, Festuca rubra, grasslads

\section{INTRODUCTION}

Most grasslands are artificial products of man and his animals. By creating an optimum balance between pasture and animals, we ensure the maintenance and permanent improvement of the vegetal cover. Only by directing the mutual interaction between the two factors - plant and animal - can be achieved positive economic results (Rotar and Carlier, 2005). The grasslands rich in species with different color combinations play an essential role in the landscape and create a particular aspect (Gârda, 2009). Schupbach et al. (2004), say the meadows play an essential role in the land of the Swiss mountains. Color combinations in natural meadows at all levels (from plain to mountain) are vital signs of a healthy environment (Rotar et al., 2003).

This work combines aspects of semi-natural meadows with high diversity in the Apuseni Mountains. From an agronomic point of view, discussing the possibilities with regard to the applicability and the effects of alternative treatments for the maintenance of the floristic composition and the natural productivity of the geasslands in the research area. The research is focused on the identification of indicator species for different quantities and doses of fertilizers applied for this area, which in our country are not 
studied enough. The research is in 2015 and the study of this paper will present the data from the organic fertilized experience.

Semi-natural grassland in the Central area of Apuseni Mountains, Romania is fertilized only with organic fertilizers. Manure from cows and horses is applied in quantities of 6 to $10 \mathrm{Mg} \mathrm{ha}^{-1}$ (Plesa et al., 2015).

Traditionally managed in Central European mountain grasslands have high nature conservation value because of their high species diversity. Whether these grasslands and their diversity can be preserved will depend on many factors, including how plant species composition responds to changes in climate conditions (Pacurar et al., 2014)

The main goal is the ecological and fodder evaluation of semi-natural grasslands based on the floristic composition. The objectives of the works are: the changes that occur at the level of the canopy following the application of technological inputs; the influence of organic fertilizers on the productivity of grasslands and the influence of organic fertilizer application on grassland biodiversity.

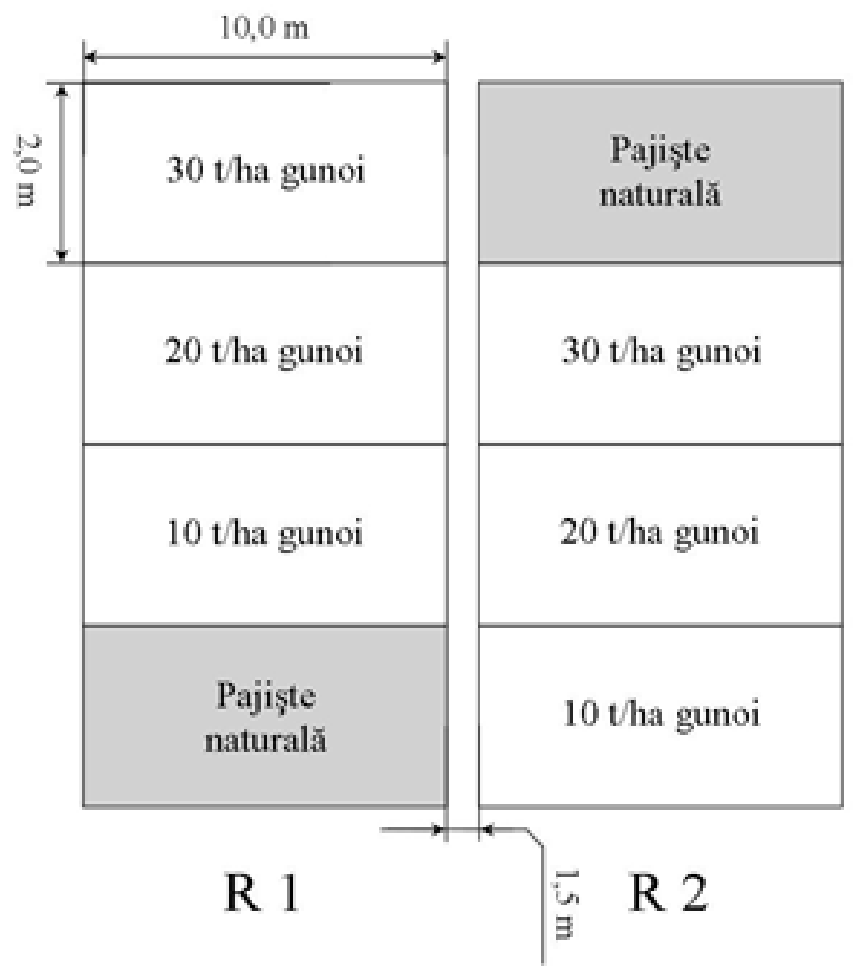

\section{MATERIAL AND METHODS}

The experimental protocol: The experience was based on the randomized four-reel method with four variants.

V1- control manure

V2-10 t/ha manure

V3-20 t/ha manure

V4-30 t/ha manure

Statistical data processing. For the processing and analysis of vegetation data obtained in experimental fields in the first year we used the PC-ORD version 6 software, which makes the set of analytical tools appropriate to our nonlinear data available (www.pcord.com).

The program can perform multivariate analysis of the ecological data entered into the spreadsheets, perceived as an analysis matrix. The structure of this program focuses on nonparametric instruments (tests), graphical representation and randomization of vegetation data. A detailed description of the accessible statistical tools and their appropriate application can be found in the Mccune (2002) and Peck (2010).

In this paper we used the Multi-dimensional Non-Metric Scaling (NMDS), MRPP (Multi Res-
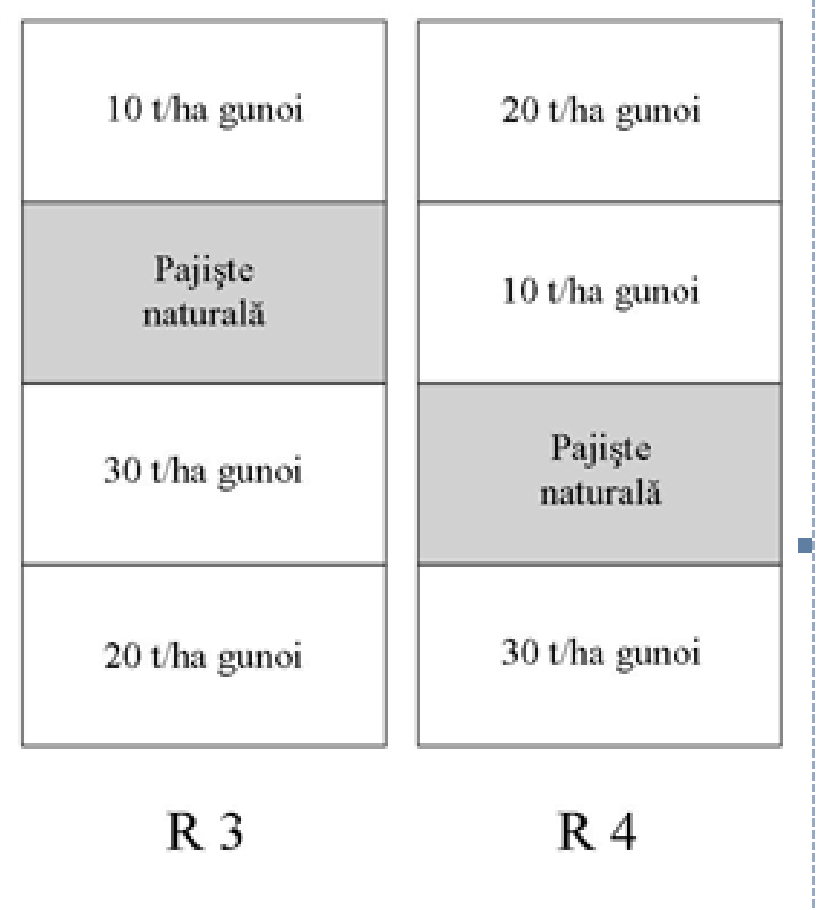

Fig. 1. Plan of experience 
Tab. 1. The importance of axes, the final stress and the recommended ordering space

\begin{tabular}{|c|c|c|c|c|c|}
\hline Axis & $\begin{array}{c}\text { Degree of } \\
\text { participation (r) }\end{array}$ & Cumulative & $\begin{array}{l}\text { The ultimate } \\
\text { stress }\end{array}$ & Signified. & $\begin{array}{l}\text { Suggested solution for graphic } \\
\text { representation }\end{array}$ \\
\hline 1 & 0.900 & 0.900 & \multirow{2}{*}{7.265} & \multirow{2}{*}{$* *$} & \multirow{2}{*}{$2 \mathrm{D}$} \\
\hline 2 & 0.043 & 0.943 & & & \\
\hline
\end{tabular}

Note: $r$ - the determination coefficient for the correlations between the ordinal distances and the original distances in dimensional space

Tab. 2. Correlation of the experimental factors (vectors) with the ordering axes in the year

\begin{tabular}{cccccc}
\hline \multirow{2}{*}{ Experimental Factors } & \multicolumn{3}{c}{ Axis 1 } & \multicolumn{2}{c}{ Axis 2 } \\
\cline { 2 - 5 } & $\mathrm{r}$ & Signified. & $\mathrm{r}$ & Signified. \\
\hline $10 \mathrm{t} / \mathrm{ha}$ & -0.165 & $\mathrm{~ns}$ & 0.352 & $\mathrm{~ns}$ \\
\hline $20 \mathrm{t} / \mathrm{ha}$ & 0.327 & $\mathrm{~ns}$ & 0.055 & $*$ \\
\hline $30 \mathrm{t} / \mathrm{ha}$ & 0.678 & $\mathrm{~ns}$ & -0.227 & $\mathrm{~ns}$ \\
\hline Harvest & 0.956 & $\mathrm{~ns}$ & -0.070 & $*$ \\
\hline Number species & -0.941 & $\mathrm{~ns}$ & -0.053 & $*$ \\
\hline Shanon & -0.642 & $\mathrm{~ns}$ & 0.522 & $\mathrm{~ns}$ \\
\hline
\end{tabular}

ponse Permutation Procedure), and ISA from the multitude of statistical tools offered by the PCORD program (Indicator Species Analysis). More general information about the methods of ordering and applicability in the field of ecology can be found in Legendre (2012), and more specifically, for vegetal associations in Cristea (2004).

How to interpret the graphs for grassland vegetation data is detailed in the Pacurar (2014). For the processing of production data, the POLIFACT program was used to test the $\mathrm{T}$ and the Duncan test to determine whether the treatments applied had any effect on the yield of the grassland type.

\section{RESULTS AND DISCUSSIONS}

The application of fertilizer to manure caused changes both in the productivity and in the floristic composition. These changes can be explained in a proportion of $94.3 \%$, out of which $90 \%$ of the phenomenon found explains axis 1 of ordering and $4.3 \%$ axis 2 (Tab. 1 )

Axis 1 of the NMDS ordering space is represented in the positive sector by the quantities of 20-30 t/ha of manure, and in the negative area of non-application of fertilizers (Tab. 2). Axis 2 is determined in the positive area by treatment with $10 \mathrm{t} /$ ha of manure.

The application of the treatments made important changes in the structure of canopy (Fig. 2). The type of representative grasslands of the witness (control) phytocoenosis is Festuca rubra - Agrostis capillaris, and it undergoes major alterations leading even to its disappearance. Treatment with $10 \mathrm{t} /$ ha of manure keeps the same type of grasslands, but with some changes which we will discuss below ( $\mathrm{P} \leq 0.01, \mathrm{~T}-4.269$, Tab. 3 ). Treatment with 20t/ha manjure determines the installation of the Agrostis capillaris type with Trisetum flavescens $(\mathrm{T}-4.082, \mathrm{P} \leq 0.01)$. The further increase in the amount of manure (30 t/ha) causes minor changes in the canopy and a slight increase in the dominance of the species Trisetum flavescens (T-2.815, P $\leq 0.005$ ).

In 2012, Pacurar shows that the application of organic fertilizers has led to the installation of the type Festuca rubra-Trisetum flavescens in the variant with $10 \mathrm{t} / \mathrm{ha}$ manure and Trisetum flavescens in treatments with $20 \mathrm{t} / \mathrm{ha}$ and $30 \mathrm{t} /$ ha of manure. Treatment with $10 \mathrm{t} / \mathrm{ha}$ manure has led to an increase in plant diversity, and the 
increase in the amount of manure has not led to significant changes in the number of species.

The dry matter (DM) increases proportionally as the fertilizers increase (Fig. 3). The quantity of harvest correlates very significantly $(r=0.957)$ with the treatments applied especially with the 20-30 $\mathrm{t}$ / ha manure.

The harvest of DM control is $1.56 \mathrm{t} / \mathrm{ha}$ nand after applying manure the treatments reaches up to $4.14 \mathrm{t} / \mathrm{ha} \mathrm{SU}$ (Tab. 4). Difference of harvest between control and variant with $30 \mathrm{t} /$ ha manure is $2.58 \mathrm{t} / \mathrm{ha} / \mathrm{DM}$. Application with 10 - $20 \mathrm{t} / \mathrm{ha}$ manure bring very significant increases comparative of control variant. Comparing the harvest determined the application of $20 \mathrm{t} / \mathrm{ha}$ manure with that determined by treatment with $10 \mathrm{t} / \mathrm{ha}$ manure, it is found that there is only one difference $0.39 \mathrm{t} / \mathrm{ha} / \mathrm{DM}$, which does not provide statistical assurance. Treatment with 30 t/ha manure brings a plus of $1.21 \mathrm{t} / \mathrm{ha}$ SU to the application of the $10 \mathrm{t} / \mathrm{ha}$ manure and of 0.82 t/ha DM comparative of treatments with $20 \mathrm{t} /$ ha manure, this differece identified provides statistical assurance.

Biomass harvest has developed on the following species: Trisetum flavescens (Fig. 4), Centaurea pseudophrygia (Fig. 5), Taraxacum officinale (Fig. 6), Veronica chamaedrys (Fig. 7).

The species Trisetum flavescens is strong influnced of treatments applied and has the highest share at treatments with 20 and $30 \mathrm{t} /$ ha manure $r=0.956$ (Fig. 4). The species increases its highest $2 \%$ covering (control) to $70 \%$ from grasslands to apllication of $30 \mathrm{t} / \mathrm{ha}$ manure.

The Centaurea pseudophrygia species is moderate to strongly influenced by the treatments applied and has the highest share in 20 t/ha manure $r=0.471$ (Fig. 5). Species increase their share from $23 \%$ coverage (control) to $50.5 \%$ (20 t/ha manure) and $33.5 \%$ coverage at application of $30 \mathrm{t} /$ ha manure.

The Taraxacum officinale species is moderately influenced by the treatments applied and has the highest share in 10, 20 and $30 \mathrm{t} /$ ha manure $\mathrm{r}=$ 0.604 (Fig. 6). Domination of the species increases from 2\% coverage (control) to 20.5\% (30 t/ha manure).

Veronica chamaedrys is strongly influenced by applied treatments and has the highest share of treatments at variant fertilized with $30 \mathrm{t} / \mathrm{ha}$ manure, $r=0.824$ (Fig. 7). The species increases its share in grassland from $2 \%$ coverage (control) to $55.25 \%$ (30 t/ha manure).

\section{CONCLUSIONS}

Organic fertilization causes significant changes in the floristic structure, causing changes in the dominance and the type of grasslands.

Although the number of species is reduced in all treatments, the application of $10 \mathrm{t} /$ ha manure

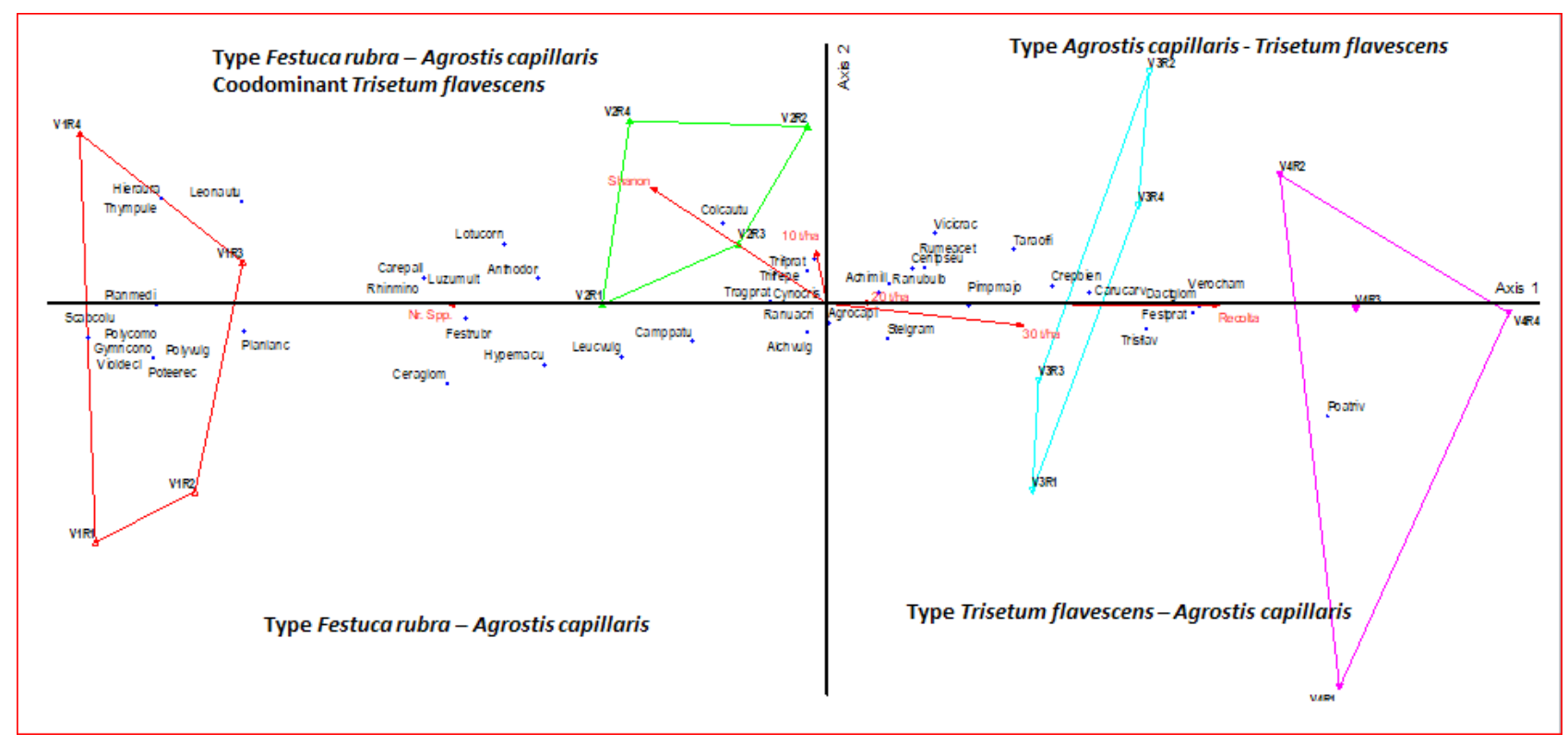

Fig. 2. The treatments influence upon phytodiversity 


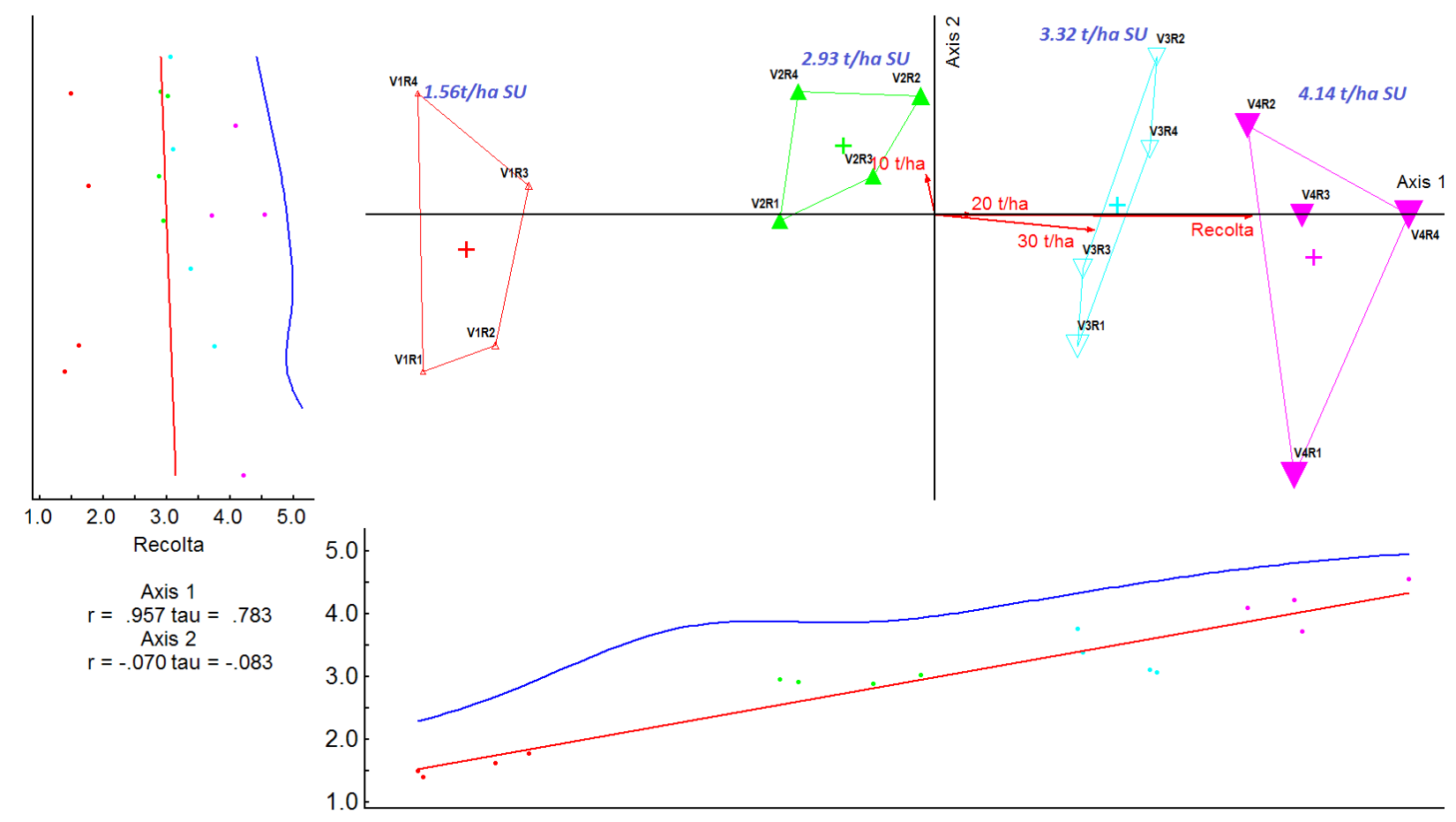

Fig. 3. The influence of treatments on the production of DM

Tab. 3. Comparison of floristic composition of experimental variants (MRPP, 2015)

\begin{tabular}{ccccc}
\hline Treatments & $\mathrm{T}$ & $\mathrm{A}$ & $\mathrm{p}$ & Signific. \\
\hline V1 vs V2 & -4.2692 & 0.3748 & 0.01 & $* *$ \\
\hline V1 vs V3 & -4.4165 & 0.4960 & 0.01 & $* *$ \\
\hline V1 vs V4 & -4.3971 & 0.4881 & 0.01 & $* *$ \\
\hline V2 vs V3 & -4.0820 & 0.3339 & 0.01 & $* *$ \\
\hline V2 vs V4 & -4.2948 & 0.3912 & 0.01 & $* *$ \\
\hline V3 vs V4 & -2.8153 & 0.1529 & 0.05 & $*$ \\
\hline
\end{tabular}

Note: V1- control; V2 - grasslands fertilized with $50 \mathrm{~kg} \mathrm{~N}$; V3 - grasslands fertilized with $100 \mathrm{~kg}$ N; V4 - grasslands fertilized with $150 \mathrm{~kg}$ N; $\mathbf{T}$ - test T, A - group homogeneity, $\mathbf{p}$ - the statistical significance

Tab. 4. The influence of organic fertlization on harvest of DM (2015)

\begin{tabular}{ccccc}
\hline Variant & t/ha & $\%$ & Difference & Signific. \\
\hline V1 & 1.56 & 100.0 & 0.00 & Mt. \\
\hline V2 & 2.93 & 187.7 & 1.37 & $* * *$ \\
\hline V3 & 3.32 & 212.3 & 1.76 & $* * *$ \\
V4 & 4.14 & 264.8 & 2.58 & $* * *$ \\
\hline
\end{tabular}

DL (p<5\%) 0.45; DL (p<1\%) 0.64; DL (p<0.1\%) 0.94 


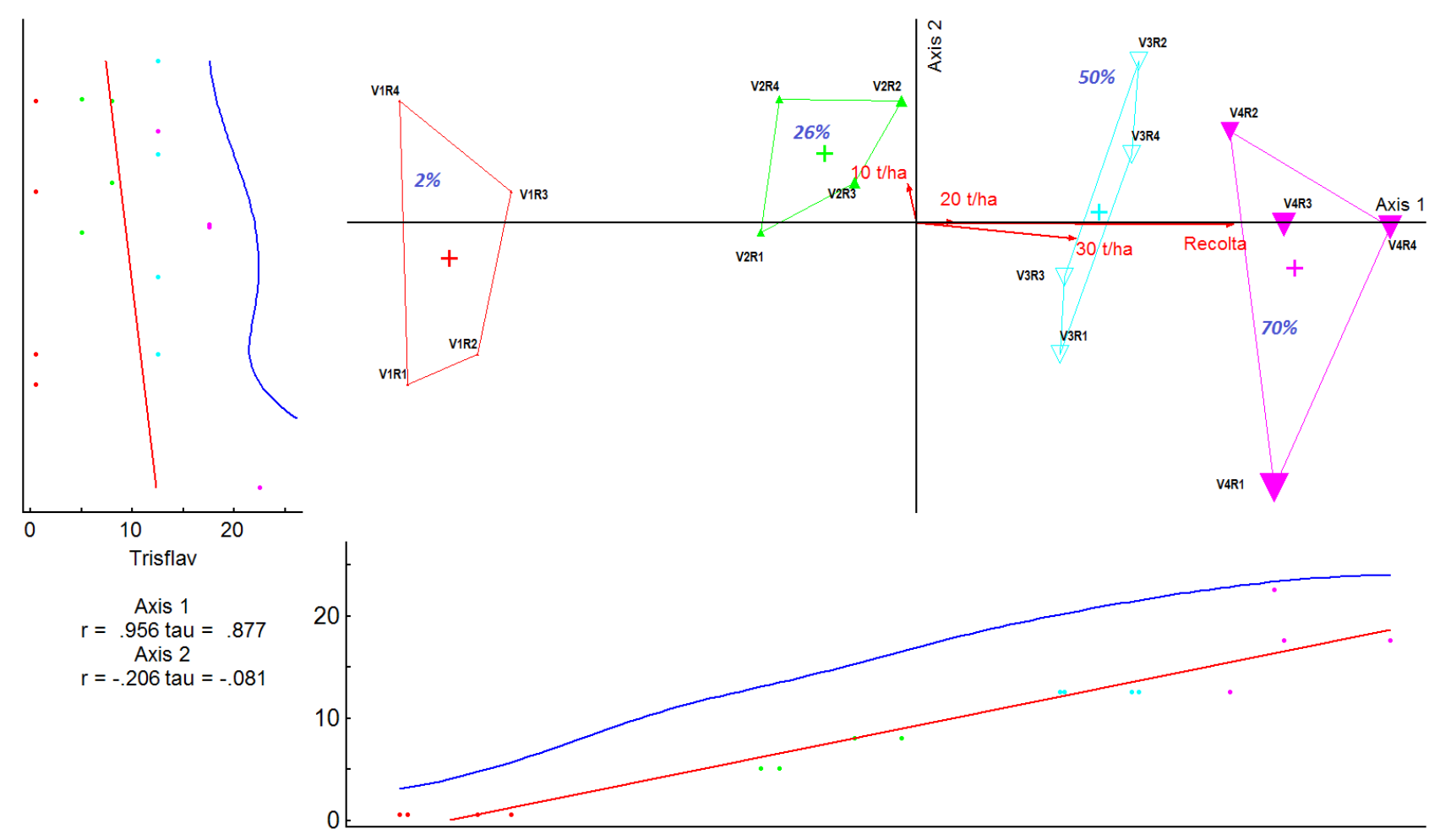

Fig. 4. The influence of species Trisetum flavescens to harvest of DM

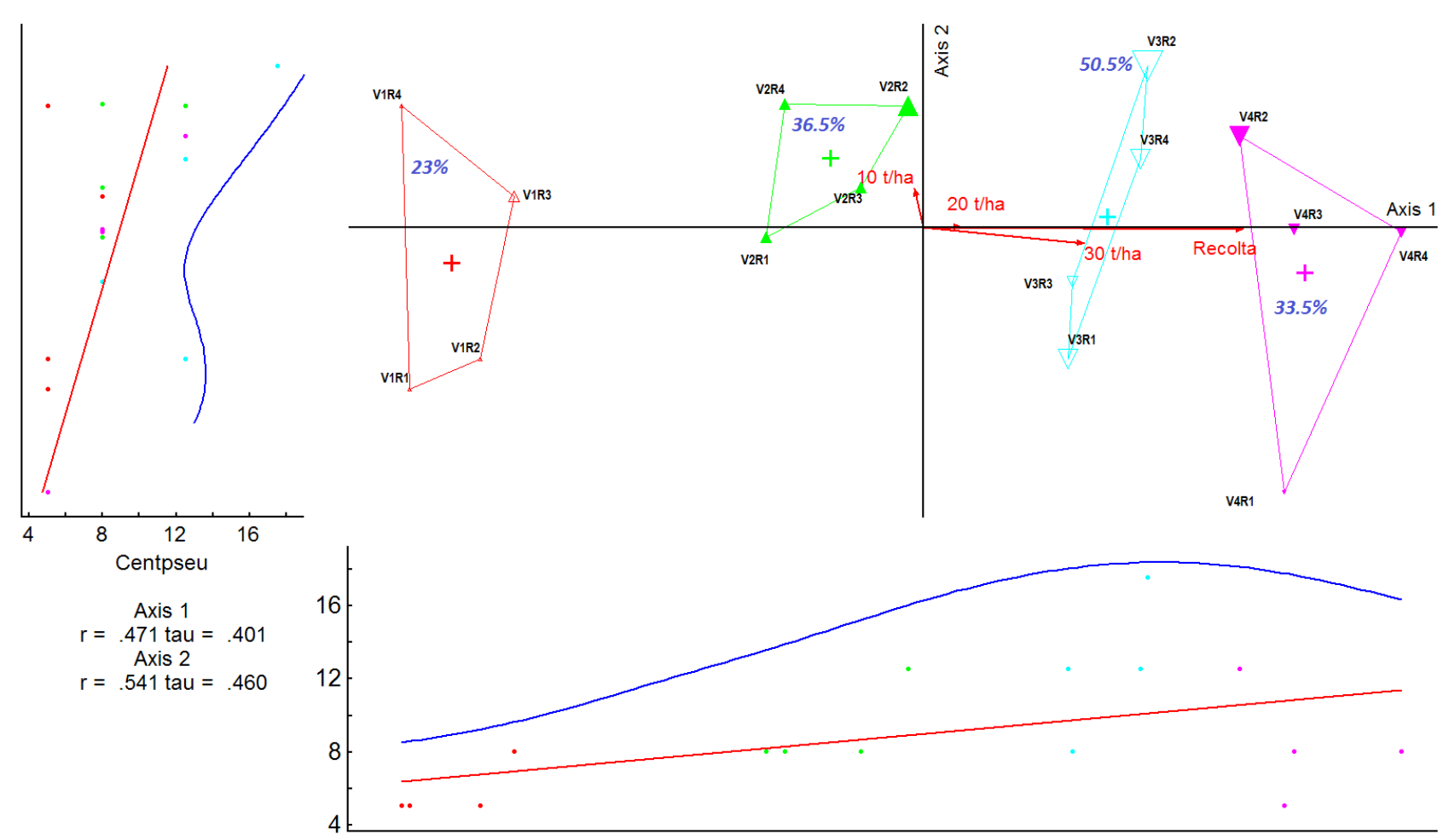

Fig. 5. The Centaurea pseudophrygia influence upon dry matter 


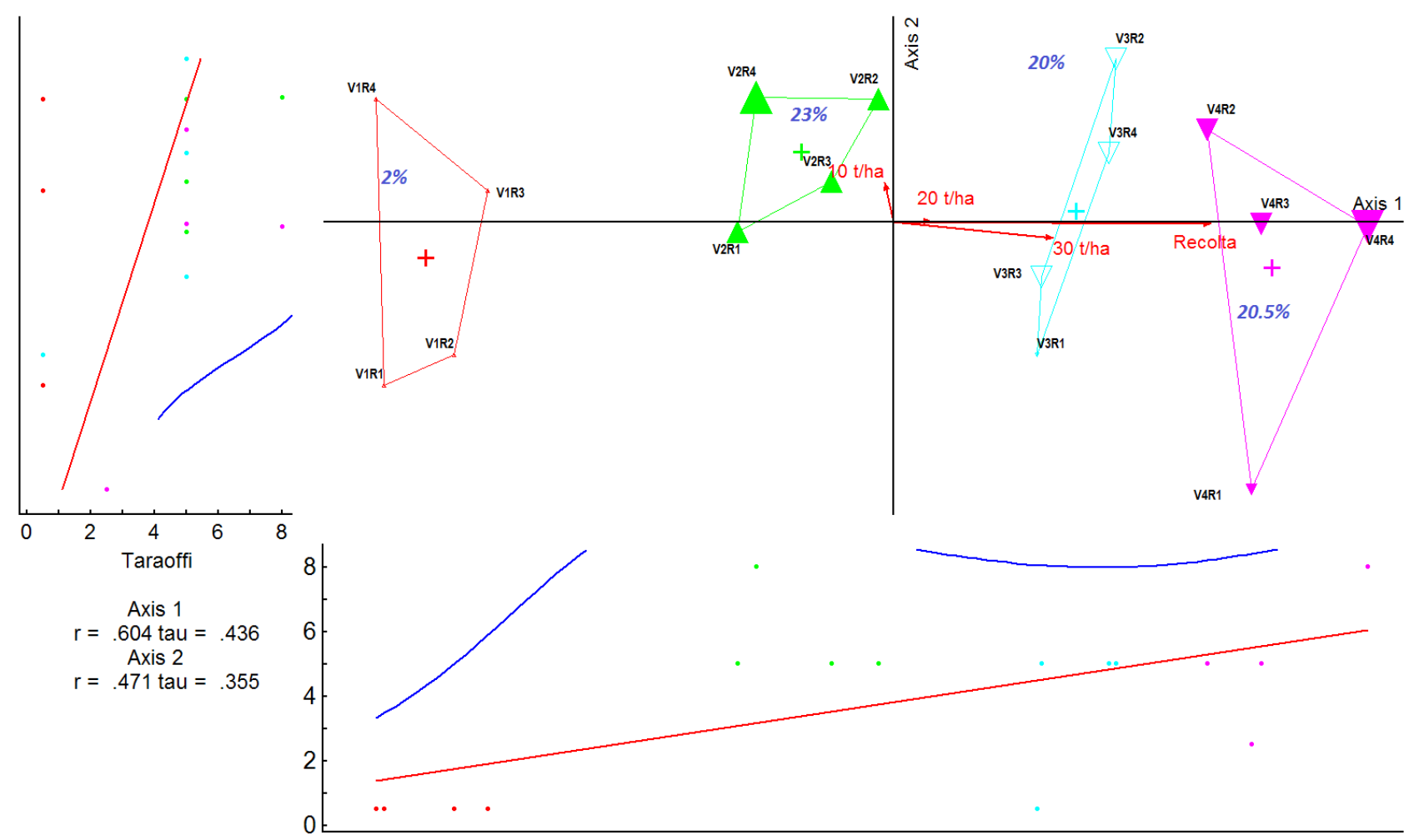

Fig. 6. The Taraxacum officinale influence upon dry matter
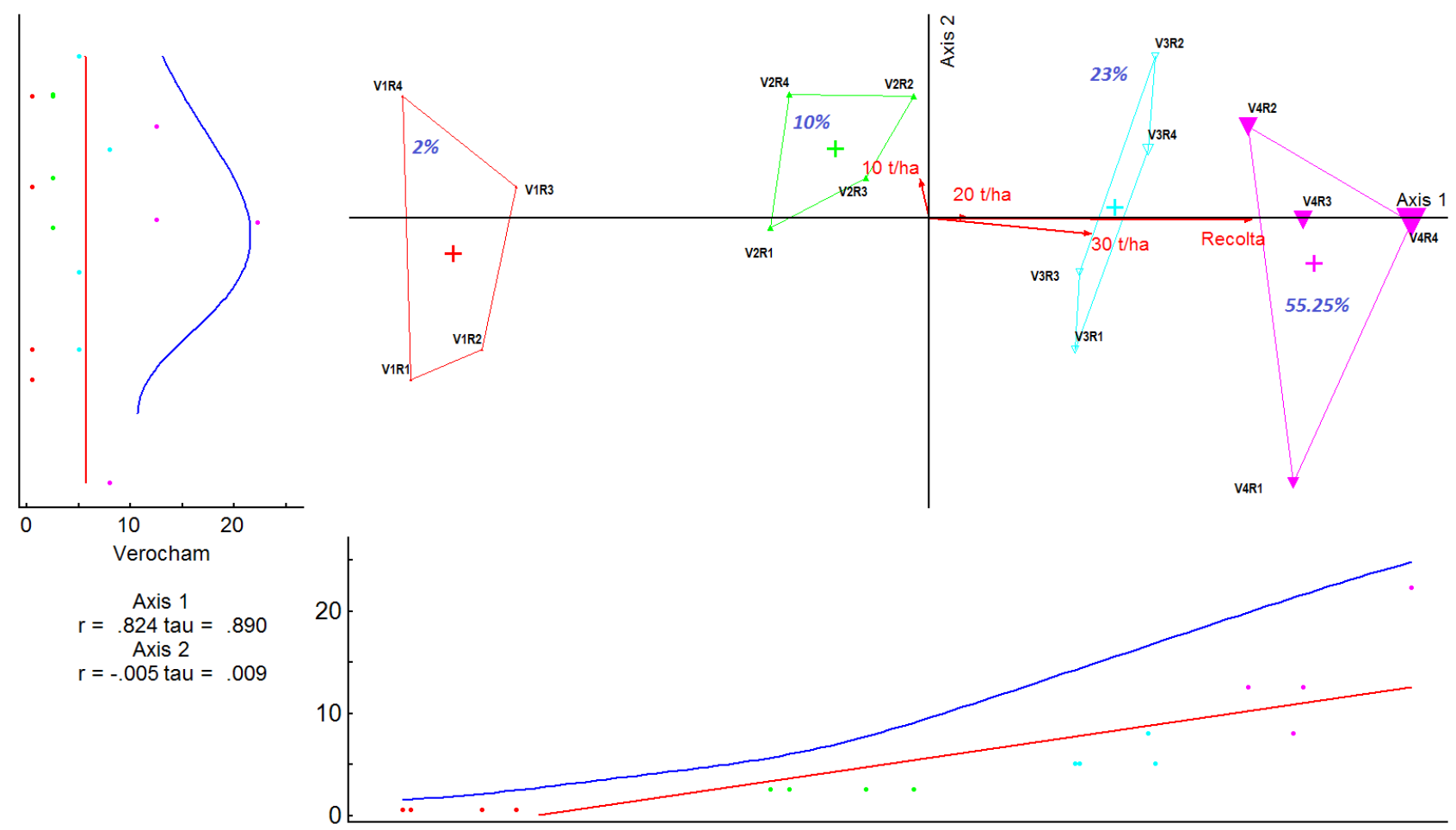

Fig. 7. The Veronica chamaedrys influence upon dry matter 
leads to an increase in phytocoenosis equivalence and, implicitly, to the Shanon index.

Dry matter (DM) yield is strongly influenced by organic fertilization, resulting in significant increases in DM.

This research did not receive any specific grant from funding agencies in the public, commercial, or not-for-profit sectors.

\section{REFERENCES}

1. Gârda NT (2009). Studiul unor elemente de landșaft montan (cu privire specială asupra ecosistemelor de pajiști din comuna Gârda de Sus, Munții Apuseni). Teză de doctorat.

2. Legendre P, Legendre L F (2012). Numerical ecology, Elsevier.

3. Mccun EB, Mefford MJ (2011). PC-ORD. Multivariate Analysis of Ecological Data. Version 6. MjM Software, Gleneden Beach, Oregon, U.S.A

4. Pacurar F, Rotar I, Reif A, Vidican R, Stoian V, Gaertner SM, Allen RB (2014). Impact of Climate on Vegetation Change in a Mountain Grassland-Succession and Fluctuation. Notulae Botanicae Horti Agrobotanici Cluj-Napoca, 42(2):347.
5. Păcurar F, Rotar I, Bogdan A, Vidican R (2012). The influence of mineral and organic long-term fertilization upon the floristic composition of Festuca rubra L.Agrostis capillaris L. grassland in Apuseni Mountains, Romania, International Journal of Food, Agriculture and Environment.

6. Păcurar F, Rotar I (2014). Metode de studiu și interpretare a vegetației pajiștilor. Editura Risoprint, Cluj-Napoca

7. Peck JE (2010). Multivariate Analysis for Community Ecologists: Step-by-Step using PC-ORD. MjM Software Design, Gleneden Beach, OR.

8. Pleșa A, Rotar I, Păcurar F, Vidican R, Balázsi A, Stoian $\mathrm{V}$ (2015). Organic fertilization on mountain grassland. In Grassland and forages in high output dairy farming systems. Proceedings of the 18th Symposium of the European Grassland Federation, Wageningen, The Netherlands, 15-17 June 2015, 289-291, Wageningen Academic Publishers.

9. Rotar I (2003). The influence of fertilization on Festuca rubra pasture biodiversity, Bulletin UASMV Cluj-Napoca, Agriculture.

10. Rotar I, Carlier L (2005). Cultura Pajiștilor, Ed. Risoprint, Cluj-Napoca.

11. www.pcord.com 